\title{
A MENTÁLIS BETEGEKET CÉLZÓ SZOLGÁLTATÁSOK HATÉKONYSÁGÁNAK FEJLESZTÉSI LEHETŐSÉGEI KÉT KOMPLEX NEMZETKÖZI PROGRAM TÜKRÉBEN
}

\author{
NAGY LÉNA ${ }^{1 *}-$ TÚRI GERGŐ ${ }^{2}$ \\ ${ }^{1}$ Eötvös Loránd Tudományegyetem, Pedagógiai és Pszichológiai Kar, Doktori Iskola \\ ${ }^{2}$ Semmelweis Egyetem, Általános Orvostudományi Kar, Népegészségtani Intézet
}

Benyújtva: 2020. október 1. - Elfogadva: 2021. április 13.

\begin{abstract}
Háttér és célkitûzések: A súlyos mentális betegségek és a betegség során elóforduló relapszusok terhei és költségimplikációi egyéni és társadalmi szinten is jelentôsek. A mentálhigiénés szolgáltatások elérhetốsége és színvonala, a kliensek egészségkimenetele és a hagyományos pszichiátriai és addiktológiai ellátás költségei azonban egyszerre javithatók innovatív kezelési, szolgáltatásszervezési és finanszírozási technikák együttes használatával. Tanulmányunk célja, hogy áttekintse a pozitív és a közösségi pszichiátriai szemléletmód, az integrált ellátásszervezés és a sikeralapú kifizetés mint innovatív finanszírozási technika alkalmazási lehetôségeit két, súlyos mentális betegek gondozásával és egészségfejlesztésével foglalkozó program bemutatásán keresztül.

Módszer: A pozitín pszichiátria, közösségi pszichiátria, az integrált ellátásszervezés és az innovatív szolgáltatásfinanszirozás koncepcióival kapcsolatban gyújtöttünk hazai és nemzetközi szakirodalmat.

Eredmények: A pozitív pszichiátria, a közösségi pszichiátria és az integrált ellátásszervezés tehermentesíthetik a költséges pszichiátriai és addiktológiai fekvốbeteg-ellátást, és elösegíthetik a szolgáltatások szinvonalának fejlesztését egy integrált ellátási folyamat részeként. A sikeralapú kifizetés modellje új típusú magánbefektetók megjelenését eredményezi, elösegíti a teljesitménymérés és -értékelés kultúrájának terjedését, és újfajta kockázatmegosztási mechanizmust alkalmaz az interszektoriális együttmüködések megvalósitásakor.

Következtetések: A közösségi pszichiátria, a pozitív pszichiátria, az integrált ellátásszervezés és a sikeralapú kifizetés számos eszközt biztosít a mentális betegeket célzó szolgáltatások fejlesztéséhez, egyúttal elôsegítve az interszektoriális együttmüködések és a hosszú távú komplex programok kialakitását. A jelen közleményben ismertetett nemzetközi példák elösegithetik a mentális betegeket célzó hazai programok fejlesztését.
\end{abstract}

Kulcsszavak: mentális egészség, pozitív pszichiátria, integrált pszichiátriai ellátás, társadalmi hatású befektetés

" Levelezô szerzố: e-mail: nagy.lena@ppk.elte.hu

(C) 2021 A szerzố(k) 


\section{BEVEZETÉS}

A mentális betegségek komoly kihívást jelentenek az egészségügyi rendszer, a társadalom és az egyének számára egyaránt. Az OECD felmérése szerint a mentális betegségekkel kapcsolatos kiadás az Európai Unióban közel 600 milliárd euró volt 2017-ben, ami az unió GDP-jének 4\%-a (OECD/EU, 2018). Ebbôl 190 milliárd euró (GDP 1,3\%) volt a közvetlen egészségügyi költség, 170 milliárd (GDP 1,2\%) a szociális ellátás költsége, és további 240 milliárd euró (GDP 1,6\%) a munkaerôpiacra tett negatív hatások közvetett költségei. A mentális betegségekkel kapcsolatos, egyre növekvố kiadások mellett az egészségügyi rendszerek számára további kihívást jelentenek a gazdasági válságok kezelése során gyakran felmerülő, állami kiadáscsökkentô intézkedések.

A súlyos és perzisztens pszichiátriai és addiktológiai zavarok a nem halálos kimenetelú betegségterhek 28\%-áért felelôsek, valamint a teljes betegségteher 10\%-áért (WHO, 2019). Magyarországon a GDP 3,1\%-át teszik ki a mentális betegségek terhei, azonban ebben még nincsenek benne a mentális betegségekkel összefüggố betegszabadságok, a munkahelyi balesetek költségei, a mentális betegséggel élók szomatikus osztályon való ellátásának magasabb költségei, és a gondozó hozzátartozók munkaerôpiaci részvételére tett hatás $(\mathrm{OECD} / \mathrm{EU}, 2018)$. A WHO a mentális betegségek terheinek csökkentése és az ellátásban előforduló társadalmi egyenlốtlenségek csökkentése érdekében kiemeli a prevenció és a költséghatékony, közösségi alapú mentális egészség szolgáltatások szerepét (WHO, 2019).

A krónikus mentális betegségek nyomán kialakuló hosszan tartó és ismétlődô hospitalizáció az egyén életvezetésére is súlyos terhet ró. A mentális betegséggel élốk körében gyakoribb a munkanélküliség vagy a munkahelyi problémák, a lakhatással kapcsolatos instabilitás és az alacsonyabb szocioökonómiai státusz (Dohrenwend, 1990; Fryers, Melzer és Jenkins, 2003; Hudson, 2005; Folsom és mtsai, 2005; WHO és Calouste Gulbenkian Foundation, 2014). A nem közfinanszírozott mentális egészség szolgáltatások gyakran a legsérülékenyebb csoportok számára nem hozzáférhetôk (Jokela, Batty, Vahtera, Elovainio és Kivimaki, 2013; Bartram, 2019), a nonprofit civil szervezetek kapacitása pedig véges, és finanszírozásuk nehézkes.

A fent említett okokból szükségessé vált a nem tervezett, pszichiátriai vagy addiktológiai fekvőbeteg-ellátásba vétel költségeinek csökkentését, illetve a páciensek és családjaik számára pszichésen és szociálisan megterhelô relapszusok megelôzését támogató szemléletváltás.

E kihívások megoldására számos új megközelítés született az elmúlt évtizedekben, melyek célja a mentális betegek egészségének fejlesztése és e klienseket célzó szolgáltatások hatékonyságának fejlesztése. A pozitív pszichiátriai és a közösségi pszichiátriai szemlélet új típusú, deinstitucionalizált pszichiátriai szolgáltatások megjelenését eredményezte, melyek az egyén és a közösség erősségeire és rezilienciájára támaszkodnak, a gyógyulás és gondozás pedig nem a közösségtôl elválasztva, hanem abba beágyazottan történik, kliensek, gondozók és gyakran tapasztalati szakértôk partneri együttmúködésével (Endre, 2019; Harangozó, 2012; Jeste, Palmer, Rettew és Boardman, 2015; Jeste, 2018).

Az integrált pszichiátriai ellátás új eszközöket adott arra, hogy a különbözố szektorokban múködố szervezetek és szereplók hatékonyan hangolják össze a mentális bete- 
geket célzó szolgáltatásaikat. Ilyen szolgáltatások alatt az eléréstôl és diagnosztizálástól kezdve a kezelésen és a rehabilitáción át, az utógondozásig és prevencióig terjedô, széles spektrumot értünk. Ezek egy integrált folyamatba szervezése és folyamatos koordinációja elôsegíti, hogy javuljon a hozzáférés, a szolgáltatások minôsége és hatékonysága, ezáltal a kliensek elégedettsége (Dózsa és Borbás, 2015).

Mindezek mellett a fejlett európai és észak-amerikai országokban a 2010-es években elterjedtté váltak az új típusú, a kormányzati és privát szektor szereplőinek együttmúködésén alapuló társadalmi hatású befektetések, melyek a pénzügyi megtérülés mellett a pozitív társadalmi hasznok elérését is célozzák. E befektetések egyik formája a siker utáni kifizetés (pay for success, továbbiakban: PFS), melynek során a kormányzat vállalja, hogy elôre rögzített társadalmi célok elérése esetén sikerdíjat fizet a befektetônek, aki elôzetesen tôkét biztosított a programok vagy szolgáltatások megvalósításához (Galloway, 2014). Az új finanszírozási technika lehetôséget teremt a közszolgáltatások hatékonyságának fejlesztésére, az innovatív programok tesztelésére.

Tanulmányunk célja, hogy a mentális betegekkel foglalkozó szakemberek megismerjék az ezen megközelítések szerint fejlesztett nemzetközi programokat, és ezáltal elôsegítsük hazai programok létrehozását, vagy meglévő szolgáltatások hatékonyságának fejlesztését. Tanulmányunkban röviden ismertetjük a pozitív pszichiátria, a közösségi pszichiátria, az integrált ellátásszervezés és a PFS koncepcióját. Ezt követôen áttekintjük két, mentális betegek egészségének fejlesztését célzó nemzetközi program gyakorlati megvalósítását, a konklúzióban összesítjük a nemzetközi példák alapján levonható tapasztalatokat és tanulságokat. A kliens szót a mentális beteg vagy mentális betegséggel élô személy szinonimájaként használjuk, különösképpen akkor, amikor a mentális egészség szolgáltatásokban elfoglalt felhasználói szerepüket kívánjuk hangsúlyozni.

\section{MÓDSZERTAN}

A szakirodalom-keresés során egyrészt a pozitív pszichiátria, közösségi pszichiátria, az integrált ellátásszervezés és az innovatív szolgáltatásfinanszírozás elméleti koncepciójával kapcsolatos elméleti koncepciókat gyújtöttünk. A szakirodalom-keresést a PsychInfo, a Pubmed adatbázisaiban, valamint a Google Scholar keresójében végeztük az alábbi kifejezések alkalmazásával: mental health, mental illness, positive psychiatry, integrated psychological treatment, community psychiatry, community based coordination of care, financing method, pay for success, social benefit bond, social impact bond.

Az elméleti koncepciókat a gyakorlatba ültetô programok keresése során a mentális betegek hospitalizációjának csökkentését célzó programokat gyüjtöttünk, melynek során az alábbi kifejezésekkel egészítettük ki az algoritmust: hospitalization, relapse, rehospitalization. Az angol nyelven, 2014 után megjelent közlemények közül azokat válogattuk be, amelyek széles körú információkat tartalmaztak a mentális betegek hospitalizációjának csökkentését célzó programok gyakorlati megvalósításáról és tapasztalatairól. Tanulmányunkban részletesen ismertetjük a programok keretében elérhetô különféle szolgáltatásokat, a szolgáltatások szervezésének és megvalósításának módját és szereplőit, valamint a beavatkozások értékelési és finanszírozási módszereit. 


\section{EREDMÉNYEK}

\section{Pozitív pszichiátria és közösségi pszichiátria}

A pozitív pszichiátria fogalma a pozitív pszichológia alapvetéseire és eredményeire támaszkodva jött létre, annak fogalmait használja fel a mentális betegséggel élố és a veszélyeztetett populáció megértésére. A pszichiátriában képviselt gyakorlata a pozitív pszichoszociális vonások és adottságok (pl. reziliencia, optimizmus, támogató szociális környezet) feltérképezése és promotálása által segíti a minél jobb mentálhigiénés egészségkimenetel elérését. A megközelítés nem limitált egy-egy betegcsoportra, így széleskörúen alkalmazható pszichiátriai és addiktológiai betegeknél is mind a prevenció, mind a rehabilitáció területén (Jeste és mtsai, 2015; Jeste, 2018).

A pozitív pszichiátria klinikumban képviselt értékeivel jelentôs átfedést mutat a közösségi pszichiátriai szolgáltatók megközelítése, különösen, ami a szolgáltató holisztikus attitûdjét illeti a kliensek felé. A „beteg” mint ügyfél van jelen, gyógyulásában partner a szolgáltatóval, a szolgáltató pedig igyekszik csökkenteni a kliens kiszolgáltatottságát és stigmatizáltságát a rendszeren belül, alapozva annak pozitív pszichoszociális adottságaira. Mint múködési modell, a közösségi pszichiátria elônye, hogy rugalmas, a társadalmi változásokra és a közösség igényeire érzékeny; keretein belül több pszichoszociális rehabilitációs módszer alkalmazható (Endre, 2019). A klinikai ellátást kiegészítô közösségi pszichiátriai szereplôk (úgymint az akut és krónikus nappali kórházak, nappali klubok, a házi gondozás, a munkarehabilitációs tanácsadók és védett lakhatási lehetôségek) a rehabilitáció, a relapszusprevenció és az utógondozás útján tehermentesítik a pszichiátriai és addiktológiai fekvóbetegosztályokat (Harangozó, 2012).

A közösségi pszichiátriai és multidiszciplináris esetmenedzselési elemeket ötvözô Assertive Community Treatment (ACT), összehasonlítva a klinikai esetmenedzseléssel és az alap pszichiátriai ellátással, igazoltan csökkenti a mentálhigiénés fekvôbetegellátás-felvételek és a fekvoóbeteg-ellátásban töltött napok számát, ezáltal az ellátás költségeit (Ziguras és Stuart, 2000). Az ACT-rôl modellezett, a kezelôi teamekhez képest alacsony esetszámra még nagyobb hangsúlyt fektetô Intensive Case Management (ICT) modell szintén csökkentette a kórházi napok számát a standard ellátáshoz képest, miközben csökkentette a kezelésból kiesôk arányát is (Coles, 2017; Dieterich, Irving, Bergman, Khokhar, Park és Marshall, 2017).

\section{Integrált ellátásszervezés}

Az integrált pszichiátriai ellátás mint szolgáltatásszervezési modell lényege a kórházi, alapellátási, közösségi és az egyéb fellelhetô szakgondozói szolgáltatók multidiszciplináris munkacsoportokká szervezése. Ezáltal csökkenti a klinikai szolgáltatókra nehezedô terheket, és egy költséghatékonyabb gondozási modellt nyújt a kórházcentrikus ellátáshoz képest, különösen a súlyos mentális betegséggel élook gondozását illetôen (Bodrogi, 1998).

Az integrált ellátás egy formája a klinikai szolgáltatások integrálása a klinikán kívüli lakhatási támogatással vagy tanácsadással. Ilyen lehetôségek az átmeneti otthonok, melyek lakhatást és mentálhigiénés szolgáltatásokat biztosítanak az akut osztály és az 
elbocsátás közti tranzíció ideje alatt, vagy a tanácsadó szolgáltatások, melyek a megfelelô lakhatás megtalálásában és fenntartásában segítenek (Rudoler, De Oliveira, Jacob, Hopkins és Kurdyak, 2018).

Az integráció egy másik lehetséges területe a közösségi pszichiátriai szolgáltatások minél szélesebb körú beépítése az ellátásba (Dózsa és Borbás, 2015; Rosen, Gill és Salvador-Carulla, 2020). A pszichiátriai fekvóbeteg-ellátás kiegészítése az ugyanazon kezelối team által biztosított nappali kórházi és járóbeteg-ellátással összefügg a tünetek enyhülésével, a pszichoszociális funkcionálás javulásával (Theodoridou és mtsai, 2015).

\section{A sikeralapú kifizetés mint innovatív finanszírozási technika}

A PFS újszerúen közelíti meg a kormányzati, nonprofit és forprofit szektor közötti, szerzôdésben rögzített együttmúködéseket, mivel a kormányzat nem a szolgáltatásokért, hanem az elért társadalmi célokért vállal fizetési kötelezettséget (Weller és Pedersen, 2018). A koncepcióban felvázolt múködési mechanizmus öt szereplố aktív együttmúködését igényli. A folyamat elején a kormányzat kijelöli, hogy mely probléma megoldását célozza, a közvetítô szervezet pedig feltérképezi és rangsorolja a problémára reagáló, bizonyítékokon alapuló lehetséges programokat. A társadalmi hatások és a költségmegtakarítások szempontjából leginkább ígéretes program azonosítását követôen a közvetítô befektetôket keres, akik vállalják olyan programok finanszírozását, melyek a pénzügyi megtérülés mellett a pozitív társadalmi hatások elérését is ígérik.

A kormányzat megállapítja a teljesítménycélokat; a program várható költségeinek, társadalmi és gazdasági nyereségeinek, valamint a megvalósítás esetleges kockázatainak figyelembevételével meghatározza a sikerdíj mértékét. A következô lépésben a közvetítô koordinálásával a kormányzat és a befektetô szerzôdést kötnek, amely szerint a befektetô biztosítja a program megvalósításához szükséges tôke egy részét vagy teljes egészét, míg a kormányzat vállalja, hogy amennyiben a program eléri a meghatározott teljesítménycélokat, akkor a befektetônek visszafizeti a tókét, valamint a sikerdíjat. A meghatározott társadalmi csoportokat célzó kormányzati, nonprofit vagy forprofit szolgáltatók számára folyamatosan, akár már a program kezdetétôl biztosított a múködéshez, valamint a szolgáltatások biztosításához szükséges tôke.

A szolgáltató a program keretén belül bizonyítottan hatásos szolgáltatásokat biztosít a meghatározott célcsoport tagjainak, a program megvalósítását a közvetítô koordinálja és monitorozza. A program által elért hatásokat független értékelô vizsgálja és értékeli. Ha a program nem éri el a kitûzött teljesítménycélokat, akkor a kormányzat nem fizet sikerdíjat, és a befektetô tôkéjét sem fizeti vissza.

Nemzetközi példák a mentális betegek hospitalizációjának csökkentését célzó programokra

\section{The Resolve Social Benefit Bond, Ausztrália}

A 2017-ben indult program az ausztráliai New South Wales állam kezdeményezésére jött létre, célja a mentális betegséggel élôk ellátásának fejlesztése és az egészségügyi költségeik csökkentése. A program idôtávja 8 év, amely alatt 530 fó bevonását tervezik, 
egy kliens összesen két évig veheti igénybe a szolgáltatásokat (Rizello, Caridá, Trotta, Ferraro és Caré, 2018).

A program közel 50 magánszemély és alapítvány 7 millió ausztrál dollár befektetése nyomán valósul meg, akiket a Social Ventures Australia, egy PFS programok menedzselésében jártas közvetítô szervezet koordinál. A befektetôk között szerepel a szolgáltató is, mely a program költségeinek 7\%-át finanszírozza. A lehetséges résztvevôket a helyi egészségügyi igazgatási körzetek referálták a program két helyszínére (Urbis, 2019).

A szolgáltatások biztosításáért felelôs Flourish Australia egy közel 60 éves múltra visszatekintố nonprofit szervezet, mely kiemelten foglalkozik a mentális betegséggel élôk tapasztalati szakértôi támogatásával (peer support) és tapasztalati szakértô tanács-

1. táblázat. A mentális betegek hospitalizációjának csökkentését célzó ausztrál program

\begin{tabular}{|c|c|}
\hline Program neve & Resolve \\
\hline Ország & Ausztrália \\
\hline Program kezdete & 2017 \\
\hline Program hossza & 8 év \\
\hline Résztvevók száma & 530 fö \\
\hline Program célkitúzése & $\begin{array}{l}\text { A súlyos és perzisztens mentális betegséggel élók egyészségügyi } \\
\text { költségeinek csökkentése, kiemelve a hosszan tartó és/vagy ismét- } \\
\text { lôdô hospitalizáció költségeit. A résztvevôk mentális egészségének } \\
\text { megtartása és fejlesztése, állapotuk önmenedzselése, az életveze- } \\
\text { tésükre diszruptív hatású, hosszan tartó vagy gyakran ismétlôdố } \\
\text { hospitalizáció elkerülése. }\end{array}$ \\
\hline Bekerülési feltételek & $\begin{array}{l}\text { - } 18 \text { és } 64 \text { év közötti. } \\
\text { - A Nepean Blue Mountains vagy a Western New South Wales } \\
\text { egészségügyi körzethez tartozik. } \\
\text { - Az elmúlt } 12 \text { hónapban összesen } 40-270 \text { nap közötti, mentális } \\
\text { egészséggel összefüggó szabadságot vagy betegszabadságot regiszt- } \\
\text { ráltak nála, és legalább egyszer kezelték pszichiátriai fekvóbeteg- } \\
\text { ként. }\end{array}$ \\
\hline Kizárási feltételek & $\begin{array}{l}\text { - Demenciával diagnosztizáltak. } \\
\text { - Akut, kórházi fekvôbeteg-ellátásra szorulók. }\end{array}$ \\
\hline Beavatkozás típusa & $\begin{array}{l}\text { Személyre és aktuális állapotra szabott intenzitású pszichoszociális, } \\
\text { mentális egészségügyi és medikális támogatás: } 24 / 7 \text { telefonvonal, } \\
\text { heti rendszerességú találkozók, közösségi események és lehetôség } \\
\text { korlátozott idejú bentlakásra. Az ellátásban fontos szerepet kap a } \\
\text { tapasztalati szakértối támogatás (peer support). }\end{array}$ \\
\hline Értékelési módszertan & Kontrollcsoportos vizsgálat. \\
\hline $\begin{array}{l}\text { Értékelés alapjául szolgáló } \\
\text { adatok }\end{array}$ & $\begin{array}{l}\text { Kvalitatív adatok a program megvalósítóival és résztvevőivel felvett } \\
\text { interjúkból, kvantitatív adatok adminisztratív forrásokból. }\end{array}$ \\
\hline Befektetett összeg & 7 millió AUD \\
\hline Sikerdij & 7,5 millió AUD (Befektetett tôke $+7,5 \%$ kamat) \\
\hline $\begin{array}{l}\text { A sikerdíjhoz kötôdô ered- } \\
\text { ményindikátorok }\end{array}$ & $\begin{array}{l}\text { Az egészzégügyi szolgáltatások igénybevételének és a hospitali- } \\
\text { zációnak a csökkentése a résztvevoók körében, a részvétel kétéves } \\
\text { időtartama alatt. }\end{array}$ \\
\hline $\begin{array}{l}\text { A tôke visszafizetési krité- } \\
\text { riuma }\end{array}$ & $\begin{array}{l}\text { A kontrollcsoporthoz viszonyítva } 25 \% \text {-os csökkenés az egészségügyi } \\
\text { szolgáltatások igénybevételében. }\end{array}$ \\
\hline
\end{tabular}


adók (peer worker) képzésével. A program által biztosított pszichoszociális támogatás a körzeti klinikai ellátás mellett komplementer szerepú. A szolgáltató a program idôtartama alatt folyamatosan kapcsolatot tart a helyi egészségügyi körzetek klinikai szolgáltatóival, és együttmúködnek az esetmenedzsment terén. Az intézmény- és programközi kapcsolatok kialakításával segítik elô, hogy egy multidiszciplináris csapat gondoskodhasson minden résztvevốról (Urbis, 2019; Social Ventures Australia, 2017, 2019, 2020).

A program alapelvei a kliensek erôsségeinek és rezilienciájának fejlesztése, a velük való partneri együttmúködés, az elérhetô és személyre szabott intervenció, valamint a klienseket támogató szociális háló kiépítése. A szolgáltató továbbá hangsúlyt fektet a kliens közösségben vállalt szerepére, támogatja az oktatásba és foglalkoztatásba való bekapcsolódásukat, és bevonja a résztvevókról gondoskodó hozzátartozókat is, figyelembe veszi az ô szükségleteiket is. A program célkitúzése a felépülés, mely pozitív pszichiátriai értelemben vett „wellness within illness”-t, vagyis a személyes célok elérését és a lehetô legjobb mentális egészségkimenetelt jelenti a kliens diagnózisához képest (Jeste és mtsai, 2015). A szolgáltatás intenzitását a kliens igényeihez és aktuális állapotához igazítják.

Az alacsony intenzitású intervenciót igénylők és a programmal még csak ismerkedôk számára 24/7 operáló telefonvonalat biztosítanak, ahol a hívásokat képzett tapasztalati szakértôk fogadják. Az alacsony és közepes intenzitású intervenciót igénylők egyéni, életvitelüket és mentális egészségüket támogató nem klinikai szolgáltatásokat vehetnek igénybe, például segítség a vásárlásban, háztartásban, pénzügyek intézésében.

Az intenzív intervenciót, de még nem hospitalizációt igénylők számára elérhetốk bentlakásos helyek. A kliensek ide állapotuk ideiglenes romlásakor jelentkezhetnek be, és átlagosan 1-4 napig maradnak, a program teljes két éve alatt maximum 21 napra jogosultak. A bentlakás idején foglalkozásokon vehetnek részt, azonban ezek nem kötelezô jellegúek. A tapasztalati szakértôk beszélgetéssel, közös főzéssel, sétával, filmnézéssel vagy kreatív programokkal támogatják az aktuális bentlakókat.

Minden résztvevô számára elérhetôk továbbá olyan heti rendszerességú csoportosszociális tevékenységek, mint a társasjáték-délutánok vagy a közös sütés-főzés. Ezek a programok strukturálják a kliensek idejét, lehetôséget teremtenek a szocializálódásra és a tapasztalati szakértôkkel való találkozásra.

Az értékelő szerepét egy független kutató és tanácsadó intézet látja el. A randomizált kontrollcsoportos vizsgálat során vizsgálják (1) a program megvalósítását, (2) a program innovativitását, (3) az intervenciók hatását a résztvevôkre és a családjukra, gondozóikra, közösségükre, (4) a program költséghatékonyságát, megtakarítási aspektusait és (5) a program nem várt következményeit. A teljesítménydíj kifizetését az egészségügyi szolgáltatások - beleértve a fekvôbeteg-ellátást - igénybevételének és költségeinek csökkentéséhez kapcsolják a résztvevôk körében, a részvétel kétéves idôtartama alatt (Deed of Implementation Agreement for Resolve Social Benefit Bond, 2017; Urbis, 2019; Social Ventures Australia, 2017, 2019, 2020).

A költség és igénybevétel helyi egészségügyben használt indikátorszámának minimum 25\%-os csökkenésétôl számít a program sikeresnek (Rizello és mtsai, 2018). Az értékelés során az adminisztratív forrásokból nyert kvantitatív adatokon túl interjúk során gyújtött kvalitatív adatokat is értékelnek. Az interjúkat a résztvevôkkel, azok 
hozzátartozóival, a szolgáltató és a körzeti ellátó kezelôszemélyzetével és tapasztalati szakértôivel, illetve a befektetôkkel is felveszik az értékelés során. Ez segít, hogy folyamatosan monitorozzák a program megvalósítását, és egy komplex képet kapjanak arról, melyek a hatékony és melyek a fejlesztendô programelemek (Nonprofit Finance Fund, 2019).

\section{Santa Clara megye PFS program, Amerikai Egyesült Államok}

A 2017-ben indult program célkitúzése a Santa Clara megye által finanszírozott pszichiátriai ellátást intenzíven igénybe vevő kliensek támogatása és az ellátás költségeinek csökkentése. A befektetô és finanszírozó egyaránt a megyei önkormányzat, a program 6 éves idôtartama alatt 250 fő bevonását tervezik. A program célcsoportjába olyan súlyos mentális betegséggel éló felnôttek tartoznak, akik gyakran kerülnek pszichiátriai sürgôsségi és fekvôbeteg-ellátásba, továbbá magasabb kockázati csoportba tartoznak a hosszan tartó hospitalizáció, a hajléktalanság vagy a bebörtönzés szempontjából (Pay for Success Agreement by and Between The County Of Santa Clara and Telecare Corporation, 2016; Nonprofit Finance Fund, 2019).

A PFS modell keretében a megyei önkormányzat szerződésre lépett a pályázat útján kiválasztott szolgáltatóval, és sikerdíjat fizet a mentálisbeteg-ellátással összefüggó megtakarítások nyomán. A Telecare Corporations néven múködô szolgáltató egy privát, forprofit szervezet, mely a múltban már bizonyíthatóan sikeresen alkalmazta közösségi mentálhigiénés programját (Assertive Community Treatment, ACT) súlyos mentális betegséggel élô felnốttek körében (Clinical Services Agreement for "Partners In Wellness" Mental Health Pay For Success Project, 2016).

Ahhoz, hogy megállapítsák, mely kliensek esetében merül fel a gyakori sürgôsségi ellátásba kerülés és a hosszan tartó hospitalizáció kockázata, egy prediktív modellt használtak, mely az egészségügyi szolgáltatások igénybevételének múltbéli mintázata alapján becsülte meg a szolgáltatások jövôbeli, várható mértékét.

Santa Clara megyében a mentális betegek ellátásával foglalkozó intézményeket a Mentálhigiénés Szolgáltatások Osztálya (Behavioral Health Services Department, BHSD) menedzseli. A lehetséges résztvevôket, akik megfelelnek a fenti kritériumoknak, a BHSD referálja a programba. A részvétel teljesen önkéntes, és az együttmúködés a páciens írásos beleegyezése után jöhet létre.

A program keretében a résztvevôk személyre szabott, átfogó, az év minden napján 24 órában elérhetô pszichoszociális támogatásban részesülnek, mely a prevenciót és a rehabilitációt is magában foglalja (Pay for Success Agreement by and Between The County Of Santa Clara and Telecare Corporation, 2016; Clinical Services Agreement for "Partners In Wellness" Mental Health Pay For Success Project, 2016). Az alkalmazott Asszertív Közösségi Ellátás (Assertive Community Treatment, ACT) az intenzív pszichiátriai és addiktológiai esetmenedzsment egy olyan megközelítése, melynek föbb jellemzője a multidiszciplináris kezelôszemélyzet; a gondozókhoz viszonyítva alacsony kliensszám; valamint az, hogy a személyzet tagjai teamként vesznek részt egy-egy kliens ellátásában, és a szolgáltatások helyszíne könnyen elérhetô a kliensek számára (Ziguras és Stuart, 2000). 
2. táblázat. A mentális betegek hospitalizációjának csökkentését célzó program Santa Clara megyében (USA)

\begin{tabular}{|c|c|}
\hline Program neve & Santa Clara County Partners in Wellness \\
\hline Ország & Amerikai Egyesült Államok \\
\hline Program kezdete & 2017 \\
\hline Program hossza & 6 év \\
\hline Résztvevôk száma & 250 fó \\
\hline Program célkitúzése & $\begin{array}{l}\text { A költséges pszichiátriai sürgôsségi és fekvôbeteg-ellátás igénybe- } \\
\text { vételének és a börtönben töltött napok számának csökkentése. } \\
\text { A mentális betegséggel élők egészségének és jóllétének megtartása } \\
\text { és javítása. }\end{array}$ \\
\hline Bekerülési feltételek & $\begin{array}{l}\text { - Mentális egészség szolgáltatások gyakori használója. } \\
\text { - Santa Clara megyei lakos. } \\
\text { - Súlyos és perzisztens mentális betegséggel él, beleértve, de nem } \\
\text { kizárólag az alábbi diagnózisokat: deluzív zavar, skizofrénia vagy } \\
\text { más pszichotikus zavar, bipoláris zavar, major depresszió, generali- } \\
\text { zált szorongás zavar, obszesszív kompulzív zavar, PTSD, borderline } \\
\text { személyiségzavar. }\end{array}$ \\
\hline Kizárási feltételek & $\begin{array}{l}\text { - } 18 \text { év alattiak, } 65 \text { év felettiek. } \\
\text { - Kizáró diagnózisok: demencia, Alzheimer-kór, katatónia, súlyos } \\
\text { autizmus, evészavarok, traumás fejsérülés, rövid pszichotikus zavar, } \\
70 \text { alatti IQ pirománia vagy pszichogén polidipszia. } \\
\text { • Súlyos szomatikus betegséggel él, melyet a szolgáltató nem tud } \\
\text { ellátni. } \\
\text { • Funkcionális problémák: nem eszik/iszik/öltözik fel, nem tudja } \\
\text { használni a mosdót, nem tud ambuláns kezelésekre járni vagy ki- } \\
\text { kelni az ágyból. } \\
\text { - Regisztrált szexuális búnelkövetô. } \\
\text { - Más programban is részt vesz. }\end{array}$ \\
\hline Beavatkozás típusa & $\begin{array}{l}\text { Asszertív Közösségi Ellátás (ACT): személyre szabott, átfogó } \\
\text { pszichoszociális intervenció, intenzív esetmenedzsment, lakha- } \\
\text { tásmenedzsment, krízisintervenció, szerhasználattal kapcsolatos } \\
\text { tanácsadás, mentális egészség intervenciók, tapasztalati szakértői } \\
\text { támogatás és egyéb elemek, amelyeket a résztvevốk személyre sza- } \\
\text { bott kezelési terve (Treatment Plan) elôír. }\end{array}$ \\
\hline Értékelési módszertan & \begin{tabular}{|l|} 
Randomizált kontrollcsoportos vizsgálat \\
\end{tabular} \\
\hline $\begin{array}{l}\text { Értékelés alapjául } \\
\text { szolgáló adatok }\end{array}$ & $\begin{array}{l}\text { Rutinszerúen felvett adminisztratív adatok az egészségügy és igaz- } \\
\text { ságszolgáltatás területérôl. }\end{array}$ \\
\hline Sikerdíj & 11,2 millió USD \\
\hline $\begin{array}{l}\text { A sikerdíjhoz kötôdố } \\
\text { eredményindikátorok }\end{array}$ & $\begin{array}{l}\text { A pszichiátriai sürgősségi és fekvőbeteg-ellátás igénybevételének és } \\
\text { a börtönben töltött napok számának csökkenése a résztvevôk köré- } \\
\text { ben a kontrollcsoporthoz képest. }\end{array}$ \\
\hline
\end{tabular}

Mivel különbözô diagnózisokkal élô, különböző pszichoszociális szinten funkcionáló és változatos kulturális, szocioökonómiai háttérrel élő betegpopulációval foglalkoznak, így minden páciens egy egyénre szabott, a gondozókkal közösen kialakított kezelési tervet kap. A kezelési terv kidolgozásakor fizikai és mentális egészség szúréseken vesznek részt a páciensek, és a gondozókkal közösen azonosítják a jelenleg fennálló problémáikat (pl. milyen kapcsolati vagy szociális problémák gátolják a pszichés jóllét 
elérésében). Ezenkívül közösen határoznak meg legalább egy kezelési célt, valamint feltérképezik a személyes erôsségeket, melyek segíthetnek ennek elérésében.

A kezelési terv kidolgozásakor szerhasználattal (Screening, Brief Intervention, and Referral to Treatment, SBIRT) és a betegség önmenedzselésével (Illness Self-Management) kapcsolatos interjúkat, illetve motivációs interjút is alkalmaznak. Ezek az interjús módszerek segítenek még pontosabb képet kapni a résztvevô állapotáról, és a késôbbi kezelést megalapozó vagy arra motiváló rövid intervenciót is tartalmaznak.

A kezelési tervben alapvetôen a résztvevố céljaira, erốsségeire, mentális betegségének, szerhasználatának és fizikai egészségének önmenedzselésére, valamint támogató szociális hálójára építenek. A terv általános célkitûzése a kliensek testi-lelki jóllétének, rezilienciájának és megküzdésének javítása. A kezelési tervben leírt intenzív esetkezelés személyspecifikus elemein túl minden résztvevố számára elérhetố a lakhatási tanácsadás, krízisintervenció, szerhasználattal kapcsolatos tanácsadás és tapasztalati szakértôi támogatás.

A lakhatási tanácsadás külön hangsúlyt kap a programban, ennek során egy képzett tanácsadó segíti a résztvevốket a megfelelố lakhatási opciók megtalálásában, a háztartással kapcsolatos készségek elsajátításában, a fóbérlôvel való kapcsolattartásban és a konfliktusok mediálásában. A kezelési tervben továbbá megfogalmazhatók továbbtanulással kapcsolatos lépések is, így a résztvevốket oktatási programokkal, szakiskolákkal vonják együttmúködésbe, ha kellôen motiváltak, és az állapotuk erre lehetôséget ad.

Amennyiben a résztvevốk állapota igényli, a BHSD intézmények továbbra is biztosítanak számukra pszichiátriai fekvốbeteg-ellátást vagy intenzív nappali kórházi ellátást. A program kezelôszemélyzete ekkor is folyamatosan kapcsolatot tart a beteggel, és az ideiglenesen róla gondoskodó BHSD személyzettel.

A program célja a sürgốsségi pszichiátriai ellátás, a pszichiátriai fekvôbeteg-ellátás igénybevételének csökkentése, de nem célja a tervezett, rendszeres orvoslátogatások számának csökkentése, mivel ez elôsegíti az állapot hosszú távú, stabil önmenedzselését és a gyógyszeres kezeléssel való együttmúködést. A program során kiemelt szerepet kap a résztvevốk összekötése az alap BHSD pszichiátriai ellátásban dolgozó szakemberekkel, akikhez a program befejeztével is fordulhatnak.

A program független értékelését a Stanford University Pszichiátriai és Viselkedéstudományi Intézete végzi. Az értékelés során kizárólag rutinszerúen felvett, egészségügyi és igazságszolgáltatási adminisztratív adatokból dolgoznak (Nonprofit Finance Fund, 2019). A randomizált kontrollcsoportos vizsgálat során a kontrollcsoport tagjai az alap pszichiátriai ellátásban részesültek, diagnózisuknak és állapotuknak megfelelôen.

A sikerdíj kifizetését kizárólag a megyei önkormányzat által finanszírozott 24 órás mentálisegészség-ellátás összköltségeinek és a börtönben eltöltött napok számának csökkenésétôl tették függôvé. A sikerdíj nem függ a pszichiátrián és addiktológián kívüli kórházi ellátás és az ambuláns pszichiátriai vagy addiktológiai ellátás igénybevételétốl. Bár a sikerdíj kifizetését nem befolyásolja, monitorozzák a résztvevốk szubjektív életminőségét, pszichoszociális funkcionálását és szerhasználatát is (Pay for Success Agreement by and Between The County Of Santa Clara and Telecare Corporation, 2016; Clinical Services Agreement for "Partners In Wellness" Mental Health Pay For Success Project, 2016; Nonprofit Finance Fund, 2019). 


\section{KONKLÚZIÓ}

\section{A nemzetközi példák alapján levonható tapasztalatok és tanulságok}

A bemutatott programok példával szolgálnak mind a szolgáltatások és a szolgáltatásszervezés, mind a finanszírozás terén történô szemléletváltásra. Terápiás fókuszuk megegyezik a pozitív pszichológia, a pozitív pszichiátria, illetve a közösségi pszichiátriai szolgáltatások alapvetô értékeivel. A felépülés és állapotmenedzselés folyamatának középpontjában az egyén rezilienciájának, erôsségeinek felismerése és fejlesztése áll (Jeste és mtsai, 2015; Jeste, 2018). A rehabilitáció és relapszusprevenció hasonló hangsúlyt kap az intervenciós elemek megválasztásában, továbbá a programok alapelveihez tartozik a kliensekkel való partneri kapcsolat kialakítása, a döntésekbe való aktív bevonásuk és a megküzdésben való énhatékonyságuk növelése.

Kiemelt szerepe van a résztvevôk közösségi életbe való integrálásának, valamint egy szakemberekból és hozzátartozókból álló támogató szociális háló kialakításának, mely segíthet megelôzni a sürgôsségi klinikai ellátást igénylô helyzeteket. Ezt a célt támogathatja például a foglalkoztatási tanácsadás, a hozzátartozók bevonása a kezelésbe és a kötetlen társasági események szervezése. A programok a kliensek diagnózisához és lehetôségeihez mért legjobb egészségkimenetel elérését túzik ki célul, a minél önállóbb életvezetést és autonóm állapotmenedzselést.

Mindkét program célkitûzése, hogy a kliensek hosszú távon is sikeresen önmenedzseljék a betegségüket. Ez a pozitív és közösségi pszichiátriára jellemzó elemek, az életvezetési támogatás és a betegségmenedzsmenttel kapcsolatos készségek átadása mellett a stabil, hosszú távú együttmúködések kialakítása által történik. Ilyen együttmúködések alatt értendô például a kliensek összekötése egy-egy pszichiáterrel a jövôbeni gyógyszeres támogatás megoldására (járóbetegként), vagy a szociális, a klinikai és a közösségi szolgáltatók közötti lehetséges kliensutak feltérképezése, szolgáltatásaik integrálása, multidiszciplináris esetmenedzsmentteamek szervezése. A pszichiátriai és addiktológiai betegek személyre szabott rehabilitációja, a prevenciós hangsúly, a multidiszciplináris gondozói teamek kialakítása olyan alapelvek, melyek megfelelnek az OECD 2018-ban megjelent mentális egészség promóció irányelveinek (OECD/EU, 2018).

$\mathrm{Az}$ ismertetett programok finanszírozási módszerének egyik elônye, hogy megoldást jelenthet a gyakran wrong pocketként említett jelenségre. Ennek lényege, hogy a társadalmi, egészségi problémák hátterében gyakran komplex, több ágazatot érintố tényezôk állnak, ezért ha egy szervezet finanszíroz egy programot, annak pozitív gazdasági és társadalmi eredményei nem feltétlenül a szervezetnél vagy a szervezethez kapcsolódó ágazatánál jelennek meg, így hosszú távon nem feltétlenül érdekelt a program fenntartásában (Roman, 2015). A PFS egyrészt együttmúködésre készteti a különbözô ágazatok és szektorok szereplőit, valamint a konstrukció jellegébôl fakadóan elôsegíti a hosszú távú programok kialakítását.

A PFS további elônye, hogy új típusú magánbefektetôket von be a társadalmilag hasznos projektek finanszírozásába és a közösségi szolgáltatások fejlesztésébe. Ez lehetôséget teremt a kormányzati, nonprofit vagy magánszolgáltatók (pl. pszichológusi rendelôközösségek) kapacitásainak fejlesztésére, mely kapacitásokat a program lezá- 
rulását követôen is hasznosítani tudják e szervezetek. A PFS modell alkalmazásának hosszú távú elônye, hogy elôsegítheti az interszektoriális együttmúködések létrejöttét és a társszakmák szolgáltatói hálózatának tovább fejlôdését.

A PFS a kormányzatról a magánbefektetôre hárítja a program eredménytelen megvalósításának politikai és pénzügyi kockázatait, hiszen kizárólag a teljesítménycélok elérése esetén kell fizetnie a befektetônek. Mivel a befektetô érdekelt abban, hogy a program elérje a kitûzött eredménycélokat, ezért előnyben fogja részesíteni a tudományosan megalapozott beavatkozásokat.

A programok folyamatos monitorozása és értékelése meghatározó részét képezi a bemutatott PFS finanszírozású programoknak. A szerzôdésekben rögzített eredménymutatók nyomon követésére leginkább a randomizált kontrollcsoportos vizsgálati elrendezést használják, amely az állami és privát szereplôk számára is jól láthatóvá teszi a társadalmi hatásokat és a megtakarításokat, valamint információt szolgáltat a program hatékonyságáról. A mentális egészséggel kapcsolatos programok rigorózus monitorozásának és értékelésének fontosságára a WHO (2019) is felhívja a figyelmet, melynek célja a költséghatékony intervenciók és modellek azonosítása.

A közösségi pszichiátria, a pozitív pszichiátria, az integrált ellátásszervezés és a sikeralapú kifizetés számos eszközt biztosít a mentális betegeket célzó szolgáltatások fejlesztéséhez, egyúttal elôsegítve az interszektoriális együttmúködések és a hosszú távú komplex programok kialakítását. A tanulmányunkban ismertetett nemzetközi példák elôsegíthetik a mentális betegeket célzó hazai programok fejlesztését.

\section{IRODALOM}

Bartram, M. (2019). Income-based inequities in access to mental health services in Canada. Canadian Journal Public Health, 110(4), 395-403. DOI: https://doi.org/10.17269/ s41997-019-00204-5

Bodrogi, A. (1998). Integrált pszichiátriai ellátás az alkoholbetegek kezelésében. Pszichoterápia, Supplementum 1, 65-75.

Deed of Implementation Agreement for Resolve Social Benefit Bond (2017). Health Administration Corporation - SVA Nominees Pty Ltd. (trustee of Resolve SBB Trust).

Dieterich, M., Irving, C. B., Bergman, H., Khokhar, M. A., Park, B., \& Marshall, M. (2017). Intensive case management for severe mental illness. Schizophrenia Bulletin, 43(4), 698-700. DOI: https://doi.org/10.1093/schbul/sbx061

Dohrenwend, B. P. (1990). Socioeconomic status (SES) and psychiatric disorders. Social Psychiatry and Psychiatric Epidemiology, 25, 41-47. DOI: https://doi.org/10.1007/BF00789069

Dózsa, Cs., \& Borbás, F. (2015). Az integrált ellátás koncepcionális keretrendszere és az integráció lehetôségei az alapellátásban. Orvosi Hetilap, 156(22), 881-887.

Clinical Services Agreement for "Partners in Wellness" Mental Health Pay for Success Project (2016). County of Santa Clara - Telecare Corporation.

Coles, B. A. (2017). Intensive Case Management for Severe Mental Illness. Issues in Mental Health Nursing, 39(2), 1-3. DOI: https://doi.org/10.1080/01612840.2017.1355184

Endre, Sz. (2019). Integrált közösségi ellátások szerepe a felépülésben - egy hatékonyságvizsgálat tükrében. Disszertáció. Pécs: Pécsi Tudományegyetem.

Folsom, D. P., Hawthorne, W., Lindamer, L., Gilmer, T., Bailey, A., Golshan, S., et al. (2005). Prevalence and risk factors for homelessness and utilization of mental health services among 
10,340 patients with serious mental illness in a large public mental health system. American Journal of Psychiatry, 162(2), 370-376. DOI: https://doi.org/10.1176/appi.ajp.162.2.370

Fryers, T., Melzer, D., \& Jenkins, R. (2003). Social inequalities and the common mental disorders - A systematic review of the evidence. Social Psychiatry and Psychiatric Epidemiology, 38(5), 229-237. DOI: https://doi.org/10.1007/s00127-003-0627-2

Galloway, I. (2014). Using pay-for-success to increase investment in the nonmedical determinants of health. Health Affairs (Project Hope), 33(11), 1897-1904. DOI: https://doi.org/10.1377/ hlthaff.2014.0741

Harangozó, J. (2012). A közösségi pszichiátriai gondozás felépülés alapú értékeinek és hatékony módszereinek bemutatása a gyakorlatban. In Kis, E. Cs., \& Sz. Makó., H. (Eds), Mentálhigiéné és segítô hivatás. Fejezetek az elmélet és a gyakorlat területeiról (pp. 187-208). Pannónia Könyvek.

Hudson, C. G. (2005). Socioeconomic status and mental illness: tests of the social causation and selection hypotheses. American Journal of Orthopsychiatry, 75(1), 3-18. DOI: https://doi. org/10.1037/0002-9432.75.1.3

Jeste, D. V., Palmer, B. W., Rettew, D. C., \& Boardman, S. (2015). Positive Psychiatry: Its Time Has Come. Journal of Clinical Psychiatry, 76(6), 675-683. DOI: https://doi.org/10.4088/ JCP.14nr09599

Jeste, D. V. (2018). Positive psychiatry comes of age. International Psychogeriatric, 30(12), 1735-1738. DOI: https://doi.org/10.1017/S1041610218002211

Jokela, M., Batty, G. D., Vahtera, J., Elovainio, M., \& Kivimäki, M. (2013). Socioeconomic inequalities in common mental disorders and psychotherapy treatment in the UK between 1991 and 2009. The British Journal of Psychiatry, 202(2), 115-120. DOI: https://doi.org/10.1192/ bjp.bp.111.098863.

Nonprofit Finance Fund (2019). Pay for Success: The First 25. A Comparative Analysis of the First 25 Pay for Success Projects in the United States. Letöltve: 2020. 05. 10.: https://nff.org/sites/default/files/paragraphs/file/download/pay-for-success-first-25.pdf

OECD/EU (2018). Health at a Glance: Europe 2018: State of Health in the EU Cycle. Paris: OECD Publishing. DOI: https://doi.org/10.1787/health_glance_eur-2018-en

Pay for Success Agreement by and between the County of Santa Clara and Telecare Corporation (2016). Santa Clara County - Telecare Corporation.

Rizello, A., Caridá, R., Trotta, A., Ferraro, G., \& Caré, R. (2018). The use of payment by results in healthcare: a review and proposal. In La Torre, M., \& Calderini, M. (Eds), Social investing beyond the SIB. Evidence from the market. Palgrave Studies in Impact Finance. DOI: https://doi.org/10.1007/978-3-319-78322-2_4

Roman, J. K. (2015). Solving the wrong pocket problem. How Pay for Success Promotes Investments in Evidence Based Best Practices. Urban Institute. Letöltve: 2020. 04. 14. https://pfs.urban.org/ system/files/2000427-solving-the-wrong-pockets-problem.pdf

Rosen, A., Gill, N. S., \& Salvador-Carulla, L. (2020). The future of community psychiatry and community mental health services. Current Opinion in Psychiatry, 33(4), 375-390. DOI: https://doi.org/10.1097/yco.0000000000000620

Rudoler, D., De Oliveira, C., Jacob, B., Hopkins, M., \& Kurdyak, P. (2018). Cost Analysis of a High Support Housing Initiative for Persons with Severe Mental Illness and Long-Term Psychiatric Hospitalization. The Canadian Journal of Psychiatry, 63(7), 492-500. DOI: https:// doi.org/10.1177/0706743717752881

Social Ventures Australia (2017). Resolve social benefit bond, information memorandum. Letöltve: 2020. 05. 11. http://www.socialventures.com.au/assets/ResolveSBB-IM-web.pdf.

Social Ventures Australia (2019). Resolve social benefit bond, annual investor report. Letöltve: 2020. 05. 11. https://www.socialventures.com.au/work/resolve-sbb/ 
Social Ventures Australia (2020). Resolve social benefit bond, annual investor report. Letöltve: 2020. 05. 11. https://www.socialventures.com.au/work/resolve-sbb/

Theodoridou, A., Hengartner, M. P., Gairing, S. K., Jäger, M., Ketteler, D., Kawohl, W., et al. (2015). Evaluation of a new person-centered integrated care model in psychiatry. Psychiatric Quarterly, 86(2), 153-168. DOI: https://doi.org/10.1007/s11126-014-9310-x

Urbis (2019). Resolve social benefit bond baseline report. Australia: Urbis. DOI: https:/ / www.osii.nsw.gov.au/assets/office-of-social-impact-investment/ESA31417-Resolve-Social-Benefiline-Report-27-Aug-2019-FINAL.PDF

Weller, A., \& Pedersen, E. R. G. (2018). Pay for Success Literature Review: A PreCare Report. Frederiksberg: Copenhagen Business School, CBS.

World Health Organization and Calouste Gulbenkian Foundation (2014). Social determinants of mental health. Geneva, World Health Organization. Letöltve: 2020. 05.14. https://www.who.int/mental_health/publications/gulbenkian_paper_social_determinants_ of_mental_health/en/

World Health Organization (2019). Making the investment case for mental health: A WHO/UNDP methodological guidance note. Geneva. Letöltve: 2020. 04. 19. https://apps.who.int /iris/ bitstream/handle/10665/325116/WHO-UHC-CD-NCD-19.97-eng.pdf?sequence $=1$ \&is Allowed $=\mathrm{y}$

Ziguras, S. J., \& Stuart, G. W. (2000). A meta-analysis of the effectiveness of mental health case management over 20 years. Psychiatric Services, 51(11), 1410-1421. DOI: https://doi. org/10.1176/appi.ps.51.11.1410

\title{
POSSIBILITIES FOR IMPROVING THE EFFICIENCY OF MENTAL HEALTH SERVICES IN THE LIGHT OF COMPLEX INTERNATIONAL PROGRAMS
}

\author{
NAGY, LÉNA - TÚRI, GERGŐ
}

Background and Objectives: The burden and cost implications of serious mental illness and related relapses affect significantly both the individual and society. Access to and quality of mental health services, along with clients' health outcomes and the costs of traditional hospital-centered mental health services can be improved by the use of innovative treatment, coordination of service delivery and financing techniques. Our objective is to explore the potential uses of positive psychiatric innovation, community-based psychiatry, integrated service delivery and the "pay for success" financing model, through presenting two mental health programs delivered to clients with serious mental illness.

Methods: Literature related to positive psychiatry, community psychiatry, integrated service delivery and innovative financing have been searched and reviewed.

Results: Positive psychiatry and community-based approaches to mental health care and service can further ease the costs of inpatient care and improve the quality of services as an integrated part of a service process. The "pay for success" model enables new types of private investors, promotes rigorous measurement and assessment of performance and uses an innovative risk-sharing mechanism in the implementation of intersectoral cooperations.

Conclusion: Community psychiatry, positive psychiatry, integrated service delivery and the pay for success model of financing provide various tools to improve mental health services while enabling intersectoral cooperations and long-term, complex programs. Our objective is to support the development of local mental health programs by presenting international examples.

Keywords: mental health, positive psychiatry, integrated psychological treatment, social impact investment 
A cikk a Creative Commons Attribution 4.0 International License (https://creativecommons. org/licenses/by/4.0/) feltételei szerint publikált Open Access közlemény, melynek szellemében a cikk bármilyen médiumban szabadon felhasználható, megosztható és újraközölhetô, feltéve, hogy az eredeti szerzó és a közlés helye, illetve a CC License linkje és az esetlegesen végrehajtott módosítások feltüntetésre kerülnek. (SID_1) 